\title{
Lingual Flap Protection during Third Molar Surgery: A Literature Review
}

\author{
Giulia Petroni ${ }^{1} \quad$ Alfredo Passaretti ${ }^{2}$ Fabrizio Zaccheo ${ }^{1} \quad$ Dario Di Nardo \\ Luca Testarelli ${ }^{1}$ Andrea Cicconetti ${ }^{1}$
}

1Department of Oral and Maxillofacial Sciences, School of Dentistry, Sapienza University of Rome, Rome, Italy

2Private Practice, Rome, Italy

\begin{abstract}
Address for correspondence Dario Di Nardo, DDS, PhD, Department of Oral and Maxillofacial Sciences, Sapienza University of Rome, Via Caserta, 6, 00161 Rome, Italy (e-mail: dario.dinardo@uniroma1.it).
\end{abstract}

Eur J Dent 2021;15:776-781.

\begin{abstract}
The purpose of this review was to analyze how the retraction and protection of lingual flap (LF+) could influence the incidence of lingual nerve injury (LNI) during third molar extraction, as compared with protocols that do not involve handling of lingual tissue (LF). A literature review was performed from the "Medline" and "Scopus" medical databases, using the keywords "lingual nerve" and "third molar surgery." From the selected articles, the mean values for transitory and permanent LNI's incidence were elaborated, taking into account the group treated with LF+ technique and the group treated with LF technique. Of 480 articles, 11 studies were included in the review. The $\mathrm{LF}+$ group counted 3,866 surgeries and it resulted in a transitory LNI's mean incidence

\section{Keywords}

- lingual flap

- lingual nerve

- third molar surgery of $2.98 \pm 0.03 \%$ and a mean incidence of $0.1 \pm 0.003 \%$ for permanent LNI. The LF group counted 5,938 surgeries with, respectively, $1.92 \pm 0.02$ and $0.49 \pm 0.006 \%$ of transitory and permanent LNI's incidence mean values. The results of this study suggest that the application of LF+ techniques reduces the risk of damage and injuries of lingual nerve.
\end{abstract}

\section{Introduction}

The iatrogenic damage of lingual nerve injury (LNI) during the surgical extraction of impacted third molars represents a noteworthy event of legal and medical importance. ${ }^{1}$ Its incidence, as reported by the literature, is between 0 and $23 \%$ of surgeries, but authors are not always in accordance with its etiology, risk factors, and incidence., ${ }^{2,3}$

It is well known that the surgery of the impacted third molar represents the most frequently associated $\mathrm{LNI}^{4}{ }^{4}$ but the exact causes of this complication mainly remain unknown. ${ }^{5}$

The association between LNI and the extraction of third molars is definitely dependent on the anatomical relationship between the two structures. Many studies highlight the closeness between the lingual nerve and third molar surgery site. ${ }^{6-10}$

Some studies ${ }^{11}$ suggest that the prevention of LNI, particularly in case of permanent damage, is essential to avoid

published online August 13, 2021
DOI https://doi.org/

$10.1055 / \mathrm{s}-0041-1730042$

ISSN 1305-7456 the harmful action of rotary instruments on the lingual soft tissues that may occur during odontotomy or osteotomy. A relevant controversial topic linked to the LNI is the application of surgical techniques of elevation and lingual flap protection $(\mathrm{LF}+)$ to prevent LNI. ${ }^{12-15}$

The methods involving the manipulation of the lingual tissues during the extraction of the mandibular third molar were usually performed in hospital and contemplated the use of a Howarth's periosteal elevator for the routine execution of the lingual flap and its protection ( $\mathrm{LF}+$ ). Successively, according to the results obtained with surgical protocols developed in the United States, surgery with the elevation of only one buccal flap (LF) spread further. ${ }^{12}$ Actually, the debate on how and if lingual flap protection could affect the incidence of LNI is still open. . $^{516-22}$

This review aims to analyze the existing literature on this topic, to determine whether the $\mathrm{LF}+$ techniques are effective

\footnotetext{
(c) 2021. European Journal of Dentistry.
}

This is an open access article published by Thieme under the terms of the Creative Commons Attribution-NonDerivative-NonCommercial-License, permitting copying and reproduction so long as the original work is given appropriate credit. Contents may not be used for commercial purposes, or adapted, remixed, transformed or built upon. (https://creativecommons.org/licenses/by-nc-nd/4.0/).

Thieme Medical and Scientific Publishers Pvt. Ltd. A-12, 2nd Floor, Sector 2, Noida-201301 UP, India 
in the prevention of LNI or whether they may cause an additional risk.

\section{Materials and Methods}

\section{Literature Search}

The study selection was performed by a literature search from the "Medline" and "Scopus" medical databases, using keywords "lingual nerve" and "third molar surgery."

\section{Selection Criteria}

1. Three types of studies were taken into account:

2. Observational studies that indicate the incidence of LNI in relation to a standard surgical technical report proposed by the author.

3. Prospective randomized studies, comparing the incidence of $\mathrm{LNI}$ in relation to the use of LF or LF+ techniques.

Randomized clinical studies, comparing the incidence of LNI in relation to the use of LF or LF+ techniques.

The first type of studies was included to assess the incidence of LNI on potentially inhomogeneous data samples, in absence of dependent variables resulting from the adoption of different surgical protocols.

Each of the selected studies, through the adoption of second and third inclusion criteria, showed two randomized samples of patients: one treated with LF+ technique and the other with LF technique.

These studies were included to evaluate the differences in terms of LNI incidence between the two techniques, excluding disturbance variables occurring from the selection of nonrandomized samples.

To assess the incidence of permanent LNI, studies with follow-up of less than 6 months were excluded. To get updated results from the most recent oral surgery, studies prior to 1990 were excluded. Moreover, studies with a sample cohort less than 200 elements were also excluded.

Several publications were excluded since they reported different surgical approach, rather than the only execution (or nonexecution) of elevation and protection of lingual flap. In fact, significant differences in surgical protocols adopted within the same study were frequently observed, and it was considered a disturbing element to the data analysis.

The choice of including studies with randomized samples only led to the exclusion of numerous articles. It has been frequently noticed an association between the application of LF+ protocols and different individual risk factors for LNI, while in other studies, the LF+ and LF samples were selected using undefined criteria. Therefore, such studies were judged unfit to compare the two techniques.

\section{Results}

The search produced 480 results. From these, 69 studies reporting the incidence of $\mathrm{LNI}$ in relation to the impacted third molar extraction surgery were selected. After exclusion of 29 duplicates, 40 articles were examined. The subsequent application of inclusion criteria led to the selection of 11 studies $^{16,23-32}$ and the exclusion of 29 studies $^{5,14,33-59}$ ( - Fig. 1).

One of the excluded studies was a literature review by Pichler and Beirne in 2001. ${ }^{50}$ This study was examined to potentially expand the selection of the articles included. However, of the eight results presented in that article, three duplicates were excluded, two studies ${ }^{60,61}$ were excluded based on time criterion (prior to 1990), and the remaining three ${ }^{62-64}$ were excluded based on selection criteria.

The results of the 11 selected items are summarized in - Table 1. - Table 2 reports the excluded articles and the reasons of their exclusion. The incidence of LNI in these studies was in a range of values between 0 and $8.94 \%$ for the temporary LNI and 0 and $1.60 \%$ for the permanent LNI.

To compare the results, the mean incidence values and standard deviations of LNI obtained by the studies were elaborated, distinguishing the sample treated with LF+

\section{TOTAL RESULTS}

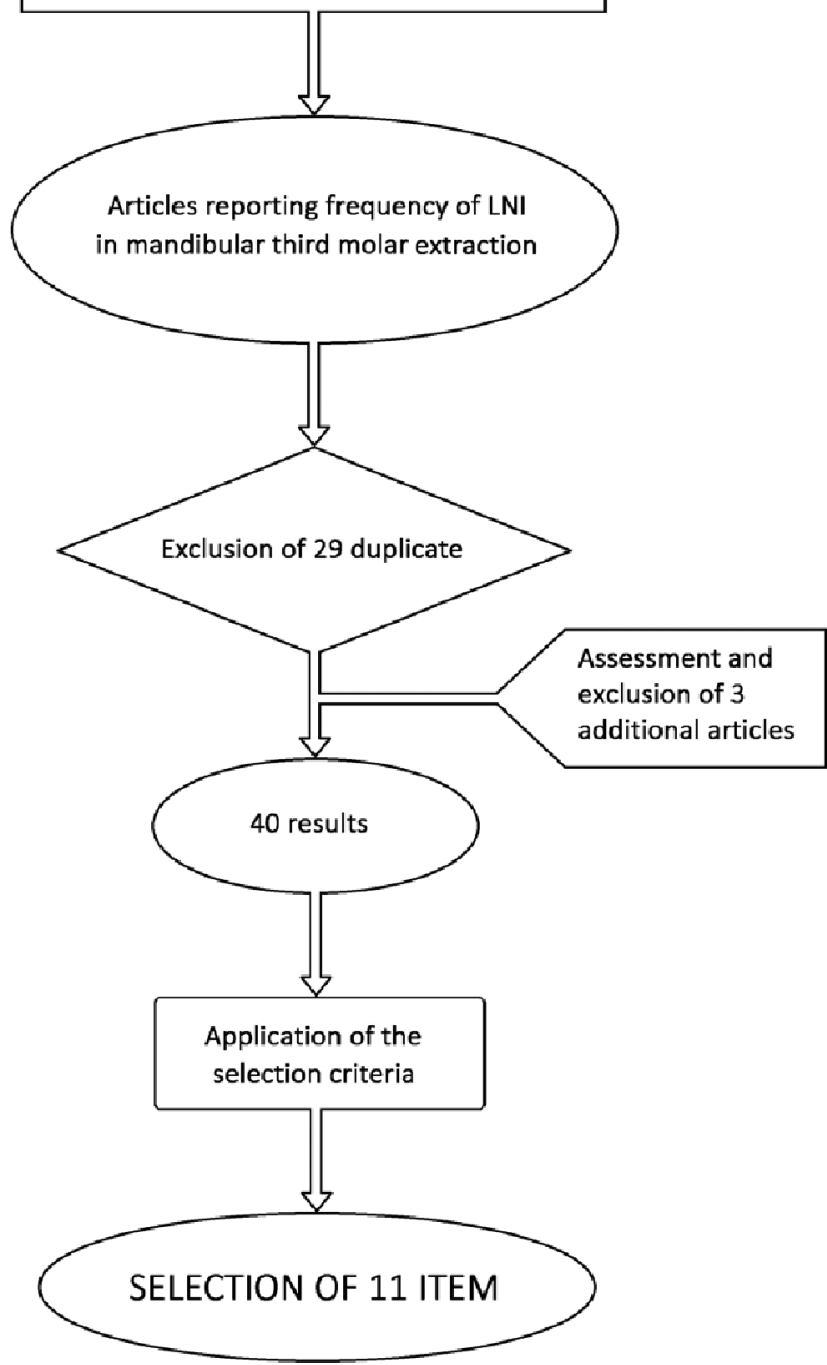

Fig. 1 Flow chart of the inclusion/exclusion criteria: from a total of 480 results, only 11 articles were considered suitable for the review. 
Table 1 List of all the included studies with the year of publication and reported incidences (\%) of temporary or permanent injuries to the inferior alveolar nerve related to the type of intervention $(\mathrm{LF}+/ \mathrm{LF})$

\begin{tabular}{|c|c|c|c|c|c|}
\hline No. & First author & Year & Technique & Temporary LNI (\%) & Permanent LNI (\%) \\
\hline \multirow[t]{2}{*}{1} & \multirow[t]{2}{*}{ Shad } & \multirow[t]{2}{*}{2015} & $\mathrm{LF}+$ & 8.94 & 0 \\
\hline & & & LF & 2.63 & 0.5 \\
\hline 2 & Jerjes & 2010 & $\mathrm{LF}$ & 1.8 & 1.6 \\
\hline 3 & Jerjes & 2006 & LF & 6.5 & 1 \\
\hline 4 & Pogrel & 2004 & LF+ & 1.6 & 0 \\
\hline 5 & Malden & 2002 & $\mathrm{LF}^{+}$ & 0.4 & 0 \\
\hline \multirow[t]{2}{*}{6} & \multirow[t]{2}{*}{ Gargallo-Albiol } & \multirow[t]{2}{*}{2000} & $\mathrm{LF}^{+}$ & 2.11 & 0 \\
\hline & & & LF & 0.63 & 0 \\
\hline \multirow[t]{2}{*}{7} & \multirow[t]{2}{*}{ Robinson } & \multirow[t]{2}{*}{1999} & $\mathrm{LF}+$ & 3.33 & 0 \\
\hline & & & LF & 0.9 & 0 \\
\hline 8 & Appiah-Anane & 1997 & $\mathrm{LF}$ & 0.2 & 0 \\
\hline 9 & Chiapasco & 1996 & $\mathrm{LF}+$ & 0.05 & 0 \\
\hline \multirow[t]{2}{*}{10} & \multirow[t]{2}{*}{ Robinson } & \multirow[t]{2}{*}{1996} & $\mathrm{LF}^{+}$ & 6.9 & 0.8 \\
\hline & & & LF & 0.9 & 0.3 \\
\hline 11 & Walters & 1995 & $\mathrm{LF}+$ & 0.5 & 0 \\
\hline
\end{tabular}

Abbreviations: LF, lingual flap; LNI, lingual nerve injury.

(3,886 surgeries) from that treated with $\operatorname{LF}$ (5,938 surgeries). The mean incidence of LNI of the cases treated with LF+ was $2.98 \pm 0.03 \%$ for the temporary injuries and $0.1 \pm 0.003 \%$

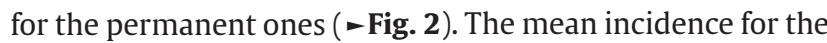
LF group was $1.92 \pm 0.02 \%$ for the temporary injuries and 0.49 $\pm 0.006 \%$ for the permanent ones ( - Fig. $\mathbf{3}$ ).

The overall incidence of injuries to the inferior alveolar nerve resulted to be higher for the $\mathrm{LF}+$ cases.

\section{Discussion}

The wide range of incidence values found in the articles (from 0 to $8.94 \%$ ) could indicate a lack of homogeneity in the management of surgical protocols adopted by different authors.

The evaluation of the elaborated average values shows that the application of LF+ technique reduces the risk of both temporary and permanent lingual nerve damages. These average values are strongly influenced by the large case series produced by Jerjes et $\mathrm{al}^{24,25}$ in the two studies taken into account in this review. These studies report an incidence of LNI after

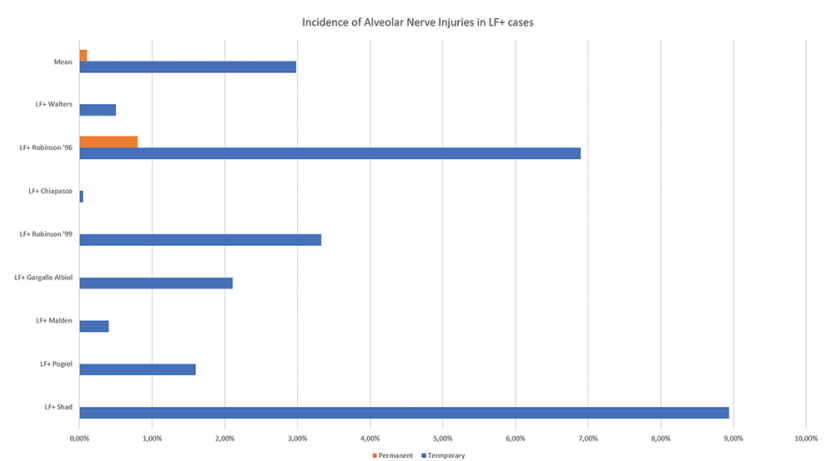

Fig. 2 Incidence (\%) of temporary and permanent injuries to the lingual nerve related to the lingual flap $(\mathrm{LF}+)$ technique.

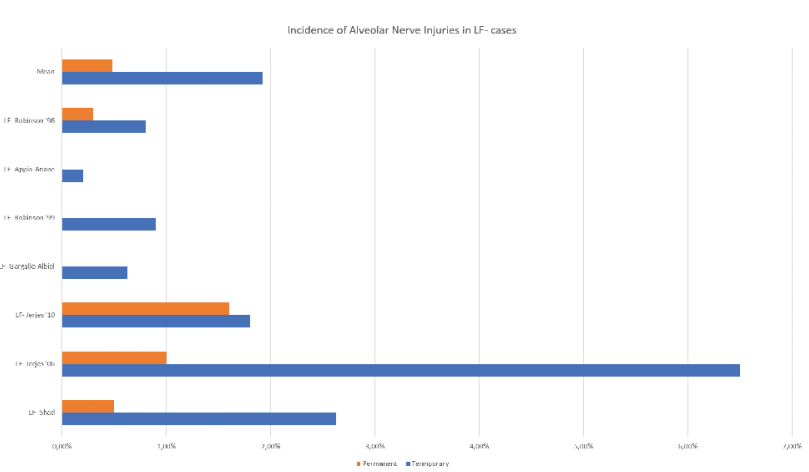

Fig. 3 Incidence (\%) of temporary and permanent injuries to the lingual nerve related to the lingual flap (LF) technique.

the application of a LF surgical protocol higher than the average incidence of the other studies in which surgeries were conducted with the same technique.

However, it must be pointed out that even without taking into account these data, the average of the values still indicates that the use of $\mathrm{LF}+$ techniques reduces the incidence of permanent LNI in comparison with LF techniques, without increasing the incidence of temporary injuries.

Back in 1997, Appiah-Anane and Appiah-Anane published a study on 504 impacted wisdom teeth treated with LF+ technique. The only complication was transient paresthesia in one patient which settled within a month. ${ }^{30}$

In the prospective study published by Pogrel and Goldman in 2004, 250 patients were treated by LF+ method. There were four cases of transient lingual paresthesia, probably caused by traction pressure from the retractor. Three of these cases resolved within 3 weeks. The fourth case completely gained sensitivity within 2 months. There were no reported cases of permanent nerve damage. ${ }^{26}$ 
Table 2 List of the excluded articles and reasons that led to their exclusion

\begin{tabular}{|c|c|c|c|c|c|c|c|}
\hline No. & First author & Year & $\begin{array}{l}\text { Nonrandomized } \\
\text { groups }\end{array}$ & $\begin{array}{l}\text { Not standardized } \\
\text { techniques }\end{array}$ & $\begin{array}{l}\text { Less } \\
\text { than } 6 \\
\text { months } \\
\text { of } \\
\text { follow-up }\end{array}$ & $\begin{array}{l}\text { Less than } \\
200 \text { third } \\
\text { molars } \\
\text { removed }\end{array}$ & Others \\
\hline 1 & Mavrodi & 2015 & $x$ & $x$ & & & \\
\hline 2 & Osunde & 2014 & $x$ & $x$ & & & \\
\hline 3 & Yadav & 2014 & $x$ & & & & \\
\hline 4 & Kale & 2014 & & & & $x$ & \\
\hline 5 & Nguyen & 2014 & & $x$ & & & \\
\hline 6 & Charan Babu & 2013 & $x$ & & $x$ & $x$ & \\
\hline 7 & Smith & 2013 & $x$ & & & & \\
\hline 8 & Guerrouani & 2013 & & $x$ & & & \\
\hline 9 & Janakiraman & 2010 & & & & $x$ & \\
\hline 10 & Cheung & 2010 & $x$ & $x$ & & & \\
\hline 11 & Baqain & 2010 & $x$ & & & & \\
\hline 12 & Akadiri & 2009 & & & & $x$ & \\
\hline 13 & Gomes & 2005 & & & & $x$ & \\
\hline 14 & Robert & 2005 & & & & & Insufficient data \\
\hline 15 & Chossegros & 2002 & & & & & Only germectomy \\
\hline 16 & Hägler & 2002 & & & & & Insufficient data \\
\hline 17 & Renton & 2001 & $x$ & $x$ & & & \\
\hline 18 & Bataineh & 2001 & $x$ & & & & \\
\hline 19 & Gülicher & 2001 & & $x$ & & & \\
\hline 20 & Ramadas & 2001 & & $x$ & & & \\
\hline 21 & Pichler & 2001 & & & & & $\begin{array}{l}\text { Study design not } \\
\text { pertinent }\end{array}$ \\
\hline 22 & $\begin{array}{l}\text { Valmaseda- } \\
\text { Castellón }\end{array}$ & 2000 & $x$ & & & & \\
\hline 23 & Gülicher & 2000 & & $x$ & & & \\
\hline 24 & Moss & 1999 & & $x$ & & & \\
\hline 25 & Brann & 1999 & & $x$ & & & \\
\hline 26 & Black & 1997 & & & $x$ & & \\
\hline 27 & Greenwood & 1994 & & & $x$ & & \\
\hline 28 & To & 1994 & & $x$ & & & \\
\hline 29 & Schultze-Mosgau & 1993 & & $x$ & & & \\
\hline 30 & Rood & 1992 & $x$ & $x$ & & & \\
\hline 31 & Carmichael & 1992 & $x$ & $x$ & & & \\
\hline 32 & Obiechina & 1990 & & $x$ & & & \\
\hline
\end{tabular}

The authors suggested that retention of the lingual plate gives optimum protection to the lingual nerve during the removal of impacted wisdom teeth.

These conclusions disagree with the quite common opinion that the surgical approach with only the buccal flap preserves the integrity of the lingual nerve, more than the $\mathrm{LF}+$ does.

It is evident that the main difficulty in drawing definitive conclusions derives from the large number of possibilities of intervention, and thus the high number of variables 
almost impossible to be taken into account simultaneously. ${ }^{21}$ Supporting this idea is the fact that even studies of similar design often report considerably different or totally opposed results, and this shows an unclear management of intervention variables that may represent a risk factor for LNI.

A possible factor leading to the spread of the theory, here refuted, according to which the application of the LF+ increases the risk of LNI, is related to the nonrandomization of the analyzed samples. In fact, it can be observed from the literature excluded from this review how, in most of the studies in which the LF+ was adopted on a selected and limited sample (on the basis of individual risk factors or other not specified factors), the incidence of the LNI increases if compared with the samples treated with LF. This result could easily depend on factors associated with sample selection, rather than the adopted surgical technique.

The analysis of the average values obtained from the selected literature would indicate a clear reduction of temporary and permanent LNIs with the use of $\mathrm{LF}+$ techniques.

Among the promoters of the LF techniques, we can mention several authors but the most relevant study was conducted by Robinson and Smith in 1996. They suggested that LF technique has a reduced incidence of LNI in comparison with the LF+ technique. ${ }^{16}$ The study by Robinson and Smith led to contrasting opinions and the debate arisen has not brought to clear and conclusive results yet: a possible explanation can be the excessive pressure made during the lingual flap protection obtained with the elevator. ${ }^{17-21}$

The results of the study by Robinson and Smith in $1996{ }^{16}$ is neither confirmed by the studies included here nor by the data that the same authors published few years late ${ }^{29}$ and the second is that the LF+ cannot be considered a risk factor for permanent LNI.

\section{Conclusion}

The results of this review suggest that the LF+ technique reduces the risk of lingual nerve damage during extraction of mandibular third molar. Moreover, the lingual flap retraction improves access to the site and can simplify the surgery.

Sometimes, there may be paresthesia, probably caused by traction pressure from the retractor, but the nature of damage is usually transitory and a complete healing is obtained in the following 2 to 6 months.

\section{Conflict of Interest}

None declared.

\section{References}

1 Lydiatt DD. Litigation and the lingual nerve. J Oral Maxillofac Surg 2003;61(2):197-200, discussion 200

2 Di Nardo D, Mazzucchi G, Lollobrigida M, et al. Immediate or delayed retrieval of the displaced third molar: a review. J Clin Exp Dent 2019;11(1):e55-e61

3 Middlehurst RJ, Barker GR, Rood JP. Postoperative morbidity with mandibular third molar surgery: a comparison of two techniques. J Oral Maxillofac Surg 1988;46(6):474-476
4 Hillerup S. Iatrogenic injury to oral branches of the trigeminal nerve: records of 449 cases. Clin Oral Investig 2007;11(2):133-142

5 Robert RC, Bacchetti P, Pogrel MA. Frequency of trigeminal nerve injuries following third molar removal. J Oral Maxillofac Surg 2005;63(6):732-735, discussion 736

6 Behnia H, Kheradvar A, Shahrokhi M. An anatomic study of the lingual nerve in the third molar region. J Oral Maxillofac Surg 2000;58(6):649-651, discussion 652-653

7 Benninger B, Kloenne J, Horn JL. Clinical anatomy of the lingual nerve and identification with ultrasonography. Br J Oral Maxillofac Surg 2013;51(6):541-544

8 Erdogmus S, Govsa F, Celik S. Anatomic position of the lingual nerve in the mandibular third molar region as potential risk factors for nerve palsy. J Craniofac Surg 2008;19(1):264-270

9 Mendes MB, de Carvalho Leite Leal Nunes CM, de Almeida Lopes MC. Anatomical relationship of lingual nerve to the region of mandibular third molar. J Oral Maxillofac Res 2014;4(4):e2

10 Karakas P, Üzel M, Koebke J. The relationship of the lingual nerve to the third molar region using radiographic imaging. $\mathrm{Br}$ Dent J 2007;203(1):29-31

11 Pogrel MA, Le H. Etiology of lingual nerve injuries in the third molar region: a cadaver and histologic study. J Oral Maxillofac Surg 2006;64(12):1790-1794

12 McGurk M, Haskell R. Wisdom tooth removal and lingual nerve damage. Br J Oral Maxillofac Surg 1999;37(4):253-254

13 Blackburn CW, Bramley PA. Lingual nerve damage associated with the removal of lower third molars. $\mathrm{Br}$ Dent J 1989;167(3):103-107

14 Rood JP. Permanent damage to inferior alveolar and lingual nerves during the removal of impacted mandibular third molars. Comparison of two methods of bone removal. Br Dent J 1992;172(3):108-110

15 Mason DA. Lingual nerve damage following lower third molar surgery. Int J Oral Maxillofac Surg 1988;17(5):290-294

16 Robinson PP, Smith KG. Lingual nerve damage during lower third molar removal: a comparison of two surgical methods. Br Dent J 1996;180(12):456-461

17 Seward GR. Protecting the lingual nerve from damage. Br J Oral Maxillofac Surg 2001;39(1):76-77

18 Walters $\mathrm{H}$. Lingual nerve damage during lower third molar removal: a comparison of two surgical methods. $\mathrm{Br}$ Dent J 1996;181(5):163-164

19 Kindelan S, McAndrew PG. Lingual nerve damage the debate continues. Br Dent J 1996;181(5):164

20 Rood JP. Lingual nerve damage. Br Dent J 1996;181(4):121

21 Pippi R, Spota A, Santoro M. Prevention of lingual nerve injury in third molar surgery: literature review. J Oral Maxillofac Surg 2017;75(5):890-900

22 Laurito D, Lollobrigida M, Graziani F, Guerra F, Vestri A, De Biase A. Periodontal effects of a transposed versus a conventional flap in mandibular third molar extractions. J Craniofac Surg 2016;27(3):708-711 doi:10.1097/SCS.0000000000002541

23 Shad S, Shah SM, Alamgir, Abbasi MM. Frequency of lingual nerve injury in mandibular third molar extraction: a comparison of two surgical techniques. J Ayub Med Coll Abbottabad 2015;27(3):580-583

24 Jerjes W, Swinson B, Moles DR, et al. Permanent sensory nerve impairment following third molar surgery: a prospective study. Oral Surg Oral Med Oral Pathol Oral Radiol Endod 2006;102(4):e1-e7

25 Jerjes W, Upile T, Shah P, et al. Risk factors associated with injury to the inferior alveolar and lingual nerves following third molar surgery-revisited. Oral Surg Oral Med Oral Pathol Oral Radiol Endod 2010;109(3):335-345

26 Pogrel MA, Goldman KE. Lingual flap retraction for third molar removal. J Oral Maxillofac Surg 2004;62(9):1125-1130 
27 Malden NJ, Maidment YG. Lingual nerve injury subsequent to wisdom teeth removal-a 5-year retrospective audit from a high street dental practice. Br Dent J 2002;193(4):203-205

28 Gargallo-Albiol J, Buenechea-Imaz R, Gay-Escoda C. Lingual nerve protection during surgical removal of lower third molars. A prospective randomised study. Int J Oral Maxillofac Surg 2000;29(4):268-271

29 Robinson PP, Loescher AR, Smith KG. The effect of surgical technique on lingual nerve damage during lower 3rd molar removal by dental students. Eur J Dent Educ 1999;3(2):52-55

30 Appiah-Anane S, Appiah-Anane MG. Protection of the lingual nerve during operations on the mandibular third molar: a simple method. Br J Oral Maxillofac Surg 1997;35(3):170-172

31 Chiapasco M, Pedrinazzi M, Motta J, Crescentini M, Ramundo G. Surgery of lower third molars and lesions of the lingual nerve. Minerva Stomatol. 1996 Nov;45(11):517-522

32 Walters $H$. Reducing lingual nerve damage in third molar surgery: a clinical audit of 1350 cases. $\mathrm{Br}$ Dent J 1995;178(4):140-144

33 Osunde O, Saheeb B, Bassey G. Indications and risk factors for complications of lower third molar surgery in a Nigerian teaching hospital. Ann Med Health Sci Res 2014;4(6):938-942

34 Mavrodi A, Ohanyan A, Kechagias N, Tsekos A, Vahtsevanos K. Influence of two different surgical techniques on the difficulty of impacted lower third molar extraction and their post-operative complications. Med Oral Patol Oral Cir Bucal 2015;20(5):e640-e644

35 Yadav S, Verma A, Sachdeva A. Assessment of lingual nerve injury using different surgical variables for mandibular third molar surgery: a clinical study. Int J Oral Maxillofac Surg 2014;43(7):889-893

36 Kale TP, Pandit VS, Patil S, Pawar V, Shetty N. Lingual guttering technique for removal of impacted mandibular third molars. J Int Oral Health 2014;6(4):9-11

37 Charan Babu HS, Reddy PB, Pattathan RK, Desai R, Shubha AB. Factors influencing lingual nerve paraesthesia following third molar surgery: a prospective clinical study. J Maxillofac Oral Surg 2013;12(2):168-172

38 Smith WP. The relative risk of neurosensory deficit following removal of mandibular third molar teeth: the influence of radiography and surgical technique. Oral Surg Oral Med Oral Pathol Oral Radiol 2013;115(1):18-24

39 Guerrouani A, Zeinoun T, Vervaet C, Legrand W.. A four-year monocentric study of the complications of third molars extractions under general anesthesia: about 2112 patients. Int J Dent 2013;2013-763837

40 Janakiraman EN, Alexander M, Sanjay P. Prospective analysis of frequency and contributing factors of nerve injuries following third-molar surgery. J Craniofac Surg 2010;21(3):784-786

41 Cheung LK, Leung YY, Chow LK, Wong MC, Chan EK, Fok YH. Incidence of neurosensory deficits and recovery after lower third molar surgery: a prospective clinical study of 4338 cases. Int J Oral Maxillofac Surg 2010;39(4):320-326

42 Baqain ZH, Abukaraky A, Hassoneh Y, Sawair F. Lingual nerve morbidity and mandibular third molar surgery: a prospective study. Med Princ Pract 2010;19(1):28-32

43 Gomes AC, Vasconcelos BC, de Oliveira e Silva ED, da Silva LC. Lingual nerve damage after mandibular third molar surgery: a randomized clinical trial. J Oral Maxillofac Surg 2005;63(10):1443-1446

44 Chossegros C, Guyot L, Cheynet F, Belloni D, Blanc JL. Is lingual nerve protection necessary for lower third molar germectomy? A prospective study of 300 procedures. Int J Oral Maxillofac Surg 2002;31(6):620-624

45 Hägler G, Reich RH. Risk and prevention of lesions of the lingual nerve in wisdom tooth osteotomy. Analysis of the literature and faculty opinion in maxillofacial surgery in German-speaking countries [in German]. Mund Kiefer Gesichtschir 2002;6(1):34-39

46 Renton T, McGurk M. Evaluation of factors predictive of lingual nerve injury in third molar surgery. Br J Oral Maxillofac Surg 2001;39(6):423-428

47 Bataineh AB. Sensory nerve impairment following mandibular third molar surgery. J Oral Maxillofac Surg 2001; 59(9):1012-1017, discussion 1017

48 Gülicher D, Gerlach KL. Sensory impairment of the lingual and inferior alveolar nerves following removal of impacted mandibular third molars. Int J Oral Maxillofac Surg 2001;30(4):306-312

49 Ramadas Y, Sealey CM. Third molar removal and nerve injury. N Z Dent J 2001;97(427):25-28

50 Pichler JW, Beirne OR. Lingual flap retraction and prevention of lingual nerve damage associated with third molar surgery: a systematic review of the literature. Oral Surg Oral Med Oral Pathol Oral Radiol Endod 2001;91(4):395-401

51 Valmaseda-Castellón E, Berini-Aytés L, Gay-Escoda C. Lingual nerve damage after third lower molar surgical extraction. Oral Surg Oral Med Oral Pathol Oral Radiol Endod 2000;90(5):567-573

52 Moss CE, Wake MJ. Lingual access for third molar surgery: a 20-year retrospective audit. $\mathrm{Br} \mathrm{J}$ Oral Maxillofac Surg 1999;37(4):255-258

53 Black CG. Sensory impairment following lower third molar surgery: a prospective study in New Zealand. N Z Dent J 1997;93(413):68-71

54 Greenwood M, Langton SG, Rood JP. A comparison of broad and narrow retractors for lingual nerve protection during lower third molar surgery. Br J Oral Maxillofac Surg 1994;32(2):114-117

55 To EW, Chan FF. Lingual nerve retractor. Br J Oral Maxillofac Surg 1994;32(2):125-126

56 Carmichael FA, McGowan DA. Incidence of nerve damage following third molar removal: a West of Scotland Oral Surgery Research Group study. Br J Oral Maxillofac Surg 1992;30(2):78-82

57 Nguyen E, Grubor D, Chandu A. Risk factors for permanent injury of inferior alveolar and lingual nerves during third molar surgery. J Oral Maxillofac Surg 2014;72(12):2394-2401

58 Akadiri OA, Fasola AO, Arotiba JT. Incidence and risk factors for nerve injuries in mandibular third molar surgery. Niger J Med 2009;18(4):402-408

59 Gülicher D, Gerlach KL. Incidence, risk factors and follow-up of sensation disorders after surgical wisdom tooth removal. Study of 1,106 cases [in German]. Mund Kiefer Gesichtschir 2000;4(2):99-104

60 Wofford DT, Miller RI. Prospective study of dysesthesia following odontectomy of impacted mandibular third molars. J Oral Maxillofac Surg 1987;45(1):15-19

61 Rood JP. Lingual split technique. Damage to inferior alveolar and lingual nerves during removal of impacted mandibular third molars. Br Dent J 1983;154(12):402-403

62 Brann CR, Brickley MR, Shepherd JP. Factors influencing nerve damage during lower third molar surgery. Br Dent J 1999;186(10):514-516

63 Schultze-Mosgau S, Reich RH. Assessment of inferior alveolar and lingual nerve disturbances after dentoalveolar surgery, and of recovery of sensitivity. Int J Oral Maxillofac Surg 1993;22(4):214-217

64 Obiechina AE. Paraesthesia after mandibular third molar extractions in Nigerians. Odontostomatol Trop 1990; 13(4):113-114 